\title{
ANALISIS STRATEGI BISNIS DALAM UPAYA MENINGKATKAN VOLUME PENJUALAN PADA \\ UMKM (Studi Kasus Bakso Super Rasa di Jalan Gayungan Surabaya)
}

\author{
Denyka Arinda Putri'; Budi Prabowo² \\ FISIP UPN "Veteran" Jawa Timur",2

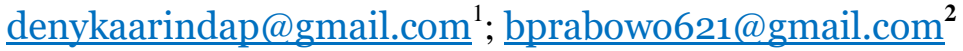

\begin{abstract}
ABSTRAK
Di era saat ini UMKM perlu memaksimalkan usahanya agar dapat bertahan hidup. Usaha Mikro Kecil yang menjadi objek penelitian ini adalah usaha Bakso Super Rasa yan berada di Jalan Gayungan Surabaya. Usaha ini merupakan usaha yang bergerak dibidang kuliner. Tujuan penelitian ini adalah untuk mengetahui dan menganalisis strategi bisnis yang digunakan Bakso Super Rasa dalam bidang keuangan, sumber daya manusia, pemasaran dan produksi dalam mempertahankan usaha dan meningkatkan pendapatan. Metode yang digunakan yaitu deskriptif kuantitatif dengan menggunakan teknik pengambilan data melalui wawancara, observasi dan dokumentasi yang berkaitan dengan strategi bisnis dalam mengidentifikasi kekuatan, kelemahan, peluang dan ancaman dengan metode SWOT pada usaha Bakso Super Rasa. Melalui analisis menggunakan IFAS (Internal Factor Analysis Summary) dan EFAS (External Factor Analysis Summary) maka dapat diketahu faktor Internal yaitu kekuatan dan kelemahan, dan faktor Eksternal yaitu peluang dan acaman. Pemilihan strategi menggunakan strategi SO, sehingga pada diagram S dan O terletak pada kuadran I yaitu perusahaan memiliki kekuatan untuk memaksimalkan peluang yang ada dengan cara meminimalkan kelemahan dan ancaman dengan mendukung kebijakan pertumbuhan yang agresif (Growth oriented strategy).
\end{abstract}

Kata Kunci : UMKM, Strategi Bisnis, Analisis SWOT

\section{ABSTRACT}

In fast changing and competitive era, small micro business needs to maximize their capability in order to survive. Small micro business which become the object of this research is Bakso Super Rasa located on Jalan Gayungan Surabaya. This business is in culinary field. The purpose of this study was to determine and analyze business strategies on finance, human resource, marketing and production in order to sustain and increase business revenue. This research uses descriptive quantitative method and research data were obtained by interviews, observation and documentation related to business strategy in identifying Strengths, Weaknesses, Opportunities and Threats (SWOT) on Bakso Super Rasa. By using analysis of IFAS (Internal Factor Analysis Summary) and EFAS (External Factor Analysis Summary) can be identified internal factors, namely strengths and weaknesses, and external factors, namely opportunities and threats. This research indicates that the choice of strategy is to use the SO strategy, so that the $S$ and $O$ diagrams are located in quadrant I, Bakso Super Rasa has the power to maximize existing opportunities by minimizing weaknesses and threats by supporting aggressive growth policies (Growth oriented strategy).

Keywords: Small Micro Business, Business Strategy, SWOT Analysis 
Diterima: 30 Maret 2021; Direvisi: 6 April 2021; Diterbitkan: 20 April 2021

\section{PENDAHULUAN}

Saat ini keberadaan usaha kecil di Indonesia sangat banyak maka tidak bisa dipungkiri bahwa suatu badan usaha sangat membantu pertumbuhan ekonomi Indonesia. Usaha kecil mempunyai peran penting karena dengan adanya usaha kecil dianggap masyarakat mampu untuk membuka lapangan pekerjaan baru. masyarakat mulai berfikir untuk menjalankan usaha kecil yang memiliki inovasi dalam menjalankan bisnis usaha kecilnya.

\section{Pengertian Usaha Mikro} Berdasarkan Undang Undang Nomor 20 Tahun 2008 tentang UMKM (Usaha Mikro Kecil dan Menengah) yaitu usaha produktif milik orang perorangan dan / atau badan usaha perorangan yang memenuhi kriteria Usaha Mikro sebagaimana diatur dalam Undang-Undang.

Para pelaku bisnis saling berlomba mempertahankan eksistensinya dan menjaga kepercayaan konsumen. Kemampuan untuk mempertahankan dan meningkatkan kemampuan bersaing dapat dilakukan antara lain dengan menerapkan strategi bisnis yang tepat. Strategi bisnis yang tepat dapat dilihat dari stabilitas tingkat penjualan atau akan lebih baik bila dapat meningkat dari tahun ke tahun sesuai dengan kuantitas atau kualitas produk yang mampu diproduksi oleh perusahaan. Dalam hal ini manajemen harus membuat suatu strategi yang mampu memanfaatkan berbagai kesempatan yang ada dan berusaha menguranggi dampak atau ancaman yang ada dan menjadikan keuntungan bagi perusahaan
Masalah yang banyak dihadapi dalam mengembangkan usaha kecil adalah masalah permodalan. Sebagian masalah modal tersebut berasal dari modal sendiri dapat juga berasal dari pinjaman bank. Selain permodalan, masalah selanjutnya yaitu bagaimana dan dimana produk itu dipasarkan. Konsentrasi pemasaran berfokus pada apakah produk itu dapat memenuhi kebutuhan konsumen yang berujung pada kepuasaan pelanggan. Proses produksi merupakan kegiatan yang dilakukan dengan menggunakan peralatan sehingga input yang dapat diolah menjadi output berupa barang jadi. Permasalahan selanjutnya yaitu sumber daya manusia, karena perlu adanya sumber daya manusia yang memiliki keahlian dan menunjang usaha.

Banyaknya pedagang yang belum mampu mempertahankan usahanya membuktikan bahwa strategi dan kreatifitas masih belum tepat, tetapi beberapa pedagang telah menjalankan usahanya sehingga dapat bertahan lama dari tahun ke tahun seperti usaha Bakso Super Rasa yang ada didaerah Gayungan Surabaya. Pemilik usaha ini dapat menunjukkan kreatifitas dalam menjalankan dan mengembangkan usahanya dari waktu ke waktu.

Menurut Freddy Rangkuti (2012:5) manajemen strategis didefinisikan sebagai seni dan pengetahuan dalam merumuskan, mengimplementasikan, serta mengevaluasi keputusan - keputusan lintas fungsional yang memampukan sebuah organisasi mencapai tujuannya.

Bakso Super Rasa dalam memproduksi baksonya dirumah pemilik yang beralamatkan di Jalan Gayungan 8 Gg 
Tomat No.03 Surabaya. Untuk tempat berjualan bakso ini di Jalan Gayungsari Timur No. 07 Surabaya (samping Bank BCA). Bakso Super Rasa berdiri pada bulan Oktober tahun 2010. Bisnis ini didirikan oleh perorangan yaitu Bapak Arif, dan kini bakso ini sudah berkembang dan bisa memiliki karyawan 4 orang untuk membantu dalam proses produksi bakso. Bakso Super Rasa juga menerima pesanan dalam jumlah besar yang biasanya untuk acara tertentu.

Salah satu metode analisis yang dapat digunakan untuk merumuskan suatu formula strategi adalah analisis SWOT. Analisis SWOT adalah suatu metode analisis yang digunakan untuk mengetahui Kekuatan (Strengths), Kelemahan (Weakness), Peluang (Opportunities), Ancaman (Threats) pada objek penelitian. Dan hasil dari analisis SWOT dapat dirumuskan suatu strategi bisnis yang tepat untuk lebih menignkatkan dan mengembangkan hasil penjualan yang akan datang.

Berdasarkan latar belakang diatas, maka rumusan masalah yaitu strategi bisnis apakah yang digunakan oleh usaha Bakso Super Rasa dalam mempertahankan usahanya?

Adapun tujuan dari penelitian ini yaitu untuk mengetahui dan menganalisis strategi bisnis yang digunakan usaha Bakso Super Rasa dalam mempertahankan usahanya

\section{LANDASAN TEORI}

\section{Pengertian Strategi}

Menurut Siagian (2016) strategi ialah rangkaian keputusan dan tindakan yang dibuat oleh manajemen untuk diimplementasikan oleh seluruh anggota organisasi untuk mencapai tujuan sebuah organisasi tersebut.

\section{Pengertian Bisnis}

Kata "bisnis" dalam Bahasa Indonesia berasal dari kata "Business" dari Bahasa Inggris yang berarti kesibukan. Kesibukan secara khusus berarti berhubungan dengan orientasi profit atau keuntungan. Secara luas bisnis berarti keadaan dimana seseorang atau sekelompok orang sibuk melakukan pekerjaan yang menghasilkan keuntungan.

\section{Pengertian Strategi Bisnis}

Dikutip oleh Joewono (2012: 3) menjelaskan bahwa strategi bisnis adalah strategi mencapai tujuan yang sering dianalogikan dengan strategi catur, yang dimana sistematika berfikir, penyusunan rencana, kesigapan melangkah, keberanian mengambil resiko dan gairah untuk memenangkan pertandingan merupakan beberapa karakteristik permainan catur yang relevan dengan praktek pengelolaan bisnis. (Soehardi \& Sable, 2019)

\section{Pengertian Manajemen Strategi}

Manajemen strategi dapat diartikan seni dan ilmu menyusun, melaksanakan dan menilai keputusan-keputusan lintas fungsi dalam suatu organisasi untuk mencapai tujuan yang telah ditentukan (Abdul dan Darsono, 2015:3)

\section{Pengertian Usaha Mikro Kecil dan Menengah}

Pengertian Usaha Mikro

Berdasarkan Undang Undang Nomor 20 Tahun 2008 tentang UMKM (Usaha Mikro Kecil dan Menengah) yaitu usaha produktif milik orang perorangan dan / atau badan usaha perorangan yang memenuhi kriteria Usaha Mikro sebagaimana diatur dalam Undang-Undang. Usaha Mikro adalah usaha produktif milik perorangan dapat 
juga berupa badan usaha perorangan yang sudah memenuhi kriteria Usaha Mikro yang telah diatur dalam Undang-Undang. Kemudian Usaha Kecil adalah usaha ekonomi produktif yang dibangun sendiri, dapat dilakukan oleh perorangan atau badan usaha yang bukan merupakan anak perusahaan atau bukan cabang perusahaan yang dimiliki, dikuasai, atau menjadi bagian baik langsung maupun tidak langsung dari usaha menengah atau usaha besar yang memenuhi kriteria Usaha Kecil yang dimaksud dalam Undang-Undang ini. Selanjutnya Usaha Menengah adalah usaha ekonomi produktif yang didirikan sendiri, dilakukan oleh perseorangan atau badan usaha bukan merupakan anak perusahaan atau cabang perusahaan yang dimiliki, dikuasai, atau menjadi bagian baik langsung maupun tidak langsung dengan usaha kecil atau usaha besar dengan jumlah kekayaan bersih atau hasil penjualan tahunan sudah diatur dalam Undang-Undang.

\section{Pengertian Strategi Fungsional}

Strategi fungsional bertujuan terhadap pengembangan dan pemeliharaan suatu kompetensi khusus (distinctive competency) yang bertujuan untuk menghasilkan keunggulan bersaing bagi suatu perusahaan. Strategi fungsional menjelaskan rincian tentang strategi bisnis dan mengatur bagaimana kegiatan utama bisnis akan dikelola. Strategi ini memainkan dua peran penting bagi bisnisnya. Yang pertama, memberikan dukungan kepada strategi bisnis secara menyeluruh. Kedua, mengembangkan cara manajer fungsional akan bekerja sehingga memastikan setiap bidang fungsionalnya mencapai kinerja yang lebih baik dari sebelumnya (Aji, 2015).

\section{Pengertian Analisis SWOT}

Analisis SWOT dijelaskan dalam buku Freddy Rangkuti (2017:19) yaitu identifikasi berbagai faktor secara sistematis untuk merumuskan strategi perusahaan. Analisis SWOT dapat memaksimalkan kekuatan (Strengths) dan peluang (Opportunities), dan dapat meminimalkan kelemahan (Weaknesses) dan ancaman (Threats).

\section{Pengertian Penjualan}

Menurut Tamrin Abdullah dan Francis Tantri (2016:3) penjualan didefinisikan sebagai bagian dari promosi dan promosi yaitu salah satu bagian dari keseluruhan pemasaran. Selanjutnya dikutip oleh Basu Swastha dan Irwan Sahaja (2014:246) penjualan merupakan proses pertukaran barang atau jasa antara penjual dan pembeli.

\section{Pengertian Profit}

Profit adalah keuntungan yang lebih yang telah peroleh pelaku bisnis dari hasil penjualan setelah dikurangi modal dan biaya produksi lainnya. Dalam menjalakan bisnisnya setiap pelaku usaha pasti menginginkan profit bagi perusahaannya.

\section{METODE PENELITIAN}

Metode yang akan diterapkan berupa deskriptif kuantitatif dengan tujuan untuk mendeskripsikan atau memberi gambaran terhadap objek yang diteliti difokuskan pada strategi bisnis usaha Bakso Super Rasa. Sugiyono (2017: 8) menjelaskan metode penelitian kuantitatif menjelaskan tentang penelitian berlandaskan pada filsafat positivism yang digunakan untuk meneliti populasi atau sampel tertentu, pengumpulan data dengan menggunakan instrument penelitian, menganalisis data yang bersifat kuantitatif atau statistik, yang berguna untuk menguji hipotesis yang telah ditetapkannya. 
Populasi dalam penelitian ini dengan pihak terkait yaitu pemilik, karyawan dan konsumen pada usaha Bakso Super Rasa.

Teknik pengambilan sampel yang digunakan dalam penelitian ini adalah purposive sampling. Purposive sampling adalah teknik penetapan sampel dengan pertimbangan tertentu. Yang dimaksud dalam penarikan sampel ini adalah informan yang paling mengetahui mengenai informasi yang akan digali dalam penelitian ini. Sehingga dapat memudahkan peneliti untuk mengetahui lebih dalam objek atau situasi social yang diteliti. Maka dari penjelasan diatas, sampel yang digunakan dalam penelitian ini adalah :

a Pemilik : Pengolah yang bertugas secara langsung mengawasi penjualan bakso pada bakso super rasa

b Karyawan : Pelayan yang bertugas membantu proses pengolahan produk dan melayani konsumen.

c Konsumen : Pria / Wanita yang sedang membeli di bakso super rasa.

Informan dalam penelitian ini adalah Pemilik Bakso Super Rasa, Karyawan yang bekerja di Usaha Bakso Super Rasa, Konsumen yang telah makan di Bakso Super Rasa.

Pada penelitian ini data primer diperoleh melalui wawancara langsung dengan informan dan melakukan observasi langsung dilapangan, dan data sekunder diperoleh melalui dokumentasi yang dapat berupa tulisan, gambaran atau media internet.

Teknik yang digunakan dalam pengumpulan data yaitu wawancara, observasi, dan dokumentasi. Dalam mengembangkan usahanya menggunakan analisis SWOT yang meliputi produksi, keuangan, sumber daya manusia, pemasaran dengan tujuan untuk mengetahui strategi bisnis yang digunakan Usaha Bakso Super Rasa dalam menjalankan dan mengembangkan bisnisnya.

Analisis SWOT merupakan identifikasi berbagai faktor secara sistematis untuk merumuskan strategi suatu perusahaan. Analisis ini dapat memaksimalkan Kekuatan (Strengths), dan Peluang (Opportunity), namun secara bersamaan dapar meminimalkan Kelemahan (Weakness), dan Ancaman (Threats). Dalam analisis SWOT terdapat matriks SWOT yaitu matriks yang dapat menggambarkan secara jelas bagaimana kekuatan dan kelemahan internal IFAS (Internal Factor Analysis Summary) yang dihadapi perusahaan dapat disesuaikan dengan peluang dan ancaman eksternal EFAS (External Factor Analysis Summary) yang dimilikinya.

Setalah menggunakan faktor strategi Internal dan Eksternal yang telah dijelaskan pada tebel IFAS dan EFAS dilanjutkan dengan memasukkan data kedalam table Matrik SWOT dan akan menghasilkan empat set kemungkinan alternative strategis. Menurut Rangkuti (2013:31) matriks ini dapat memberikan secara jelas bagaimana peluang dan ancaman dapat disesuaikan dengan kekuatan dan kelemahan yang dimilikinya. Dengan hal ini sehingga dapat memaksimalkan kekuatan dan peluang sekaligur meminimalkan kelemahan dan ancaman yang dapat mengganggu posisi dari objek yang dianalisis. Hasil analisis menggunakan matrik SWOT menghasilkan empat set yaitu strategi SO, strategi ST, strategi WO dan strategi WT.

HASIL PENELITIAN DAN PEMBAHASAN 


\section{Gambaran Umum Perusahaan}

Usaha Mikro Kecil Menengah yang menjadi objek penelitian ini adalah Usaha Bakso Super Rasa yang berada di Jalan Gayungan Surabaya. Usaha ini didirikan pada bulan Oktober 2010 oleh Bapak Arif. Bermula dari 2009 pemilik bekerja sebagai karyawan disalah satu usaha warung bakso, pemilik belajar bagaimana cara membuat bakso dengan cita rasa yang enak. Kemudian pemilik mengembangkan kembali cita rasa dari bakso tersebut dan memutuskan untuk mendirikan usaha bakso sendiri. Berasal dari keinginan pemilik untuk berwirausaha. Usaha kuliner dapat menjadi peluang yang besar karena apabila kuliner yang disajikan tersebut memiliki harga yang relatif dan kualitas yang bagus dan enak maka dapat menarik minat konsumen untuk membeli. Peluang usaha bakso cukup menarik konsumen karena makanan jenis bakso termasuk makanan favorite bagi masyarakat Indonesia.

Bakso super rasa merupakan salah satu usaha bakso yang berhasil mempertahankan usahanya dari tahun ke tahun. Untuk mempertahakan usahanya pemilik terus berinovasi menciptakan produk bakso baru yang sedang trend dikalangan masyarakat, seperti bakso mercon, bakso keju. Bakso ini juga menyediakan topping yaitu daging cincang.

Saat ini ia mempunyai 4 karyawan, 2
orang yang bertugas membantu
memproduksi bakso dan 2 orang
membantu menyajikan kepada pembeli
dan mencuci piring. Promosi yang
dilakukan pada usaha bakso super rasa ini
dilakukan dari mulut ke mulut,
memasangkan banner didepan rombong
yang memanfaatkan suasana sekitar ramai.
Dengan memanfaatkan media elektronik
saat ini, bakso super rasa terdapat pada

aplikasi Go-Food agar dapat memudahkan konsumen dalam membeli dan memanfaatkan pembayaran media elektronik OVO apabila membayar menggunakan OVO maka akan mendapatkan potongan harga sebesar $25 \%$. Dengan adanya potongan harga tersebut dapat menarim minat konsumen saat membeli.

\section{Tahap Pengumpulan Data}

\section{Data Internal}

\section{Strategi Produksi}

Strategi produksi yang dilakukan memproduksi menu pentol yang berbagai macam seperti pentol keju, pentol mercom, pentol mekar besar dan pelengkap bakso tahu tengiri udang, siomay tenggiri udang, goring panjang, goreng bulat. Kelebihan yang dimiliki yaitu selalu menjaga kualitas yang terbaik untuk produk yang ditawarkan, mulai dari cita rasa dan bahan baku yang selalu baru. Produk pentol tidak menggunakan bahan pengawet. Kuah dari bakso mempunyai rasa yang gurih karena tidak menggunakan gajih.

\section{Strategi Keuangan}

Mengelola keuangan merupakan aspek yang penting bagi kelangsungan usaha tersebut. Dalam mengelola keuangan, pemilik Bakso Super Rasa masih mengatur secara manual. Pemilik bertugas mengatur dan mengelola segala keuangan yang dikeluarkan mulai dari berbelanja bahan baku dan peralatan. Modal awal yang dikeluarkan pemilik yaitu Rp. 3.000.000. Modal tersebut berasal dari pinjaman bank. Modal tersebut digunakan pemilik untuk membeli rombong. Keuntungan yang diperoleh digunakan pemilik untuk mengembangkan usahanya 
seperti piring, gelas, mangkok, sendok dan memperbaiki tempat berjualan.

Strategi Sumber Daya Manusia

Sumber daya manusia berkaitan dengan tenaga kerja atau karyawan. Karyawan yang dipekerjakan di Bakso Super Rasa berjumlah 4 orang, 3 orang bertugas untuk membantu membuat produk, dan 1 orang bertugas membantu berjualan. Saat keadaan ditempat berjualan ramai maka ada salah satu karyawan juga yang membuat berjualan. Sistem penggajian karyawan yaitu harian lepas. Para karyawan bekerja setiap hari Senin sampai dengan Sabtu. Untuk jam kerja bagi karyawan yang membantu memasak yaitu mulai jam 10.00 WIB sampai dengan jam 16.00 WIB, untuk karyawan yang membantu berjualan memulai kerja pada pukul 16.00 WIB sampai dengan 22.00 WIB atau sampai bakso habis.

Strategi Pemasaran

Produk (Product). Memproduksi berbagai macam pentol yang dapat disukai masyarakat. Harga (Price). Harga relatif sedikit lebih mahal dibandingkan dengan pesaing disekitar tetapi pemilik selalu memberikan kualitas yang terbaik dengan harga yang ditawarkan tersebut. Promosi (Promotion). Melalui mulut ke mulut, media sosial seperti aplikasi Instagram, Facebook, Whatsapp. Pemilik juga mendaftarkan usahanya di aplikasi makanan GoFood. Tempat (Place). Pemilik diberi orang tempat berjualan yang strategis dekat dengan pemukiman warga, perkantoran, dan tempat yang ramai lalu lalang masyarakat dapat menjadikan Bakso Super Rasa diminati oleh konsumen. Walaupun hanya berjualan dengan memakai tossa tetapi pemilik berhasil bertahan lama dan sukses dalam usaha bidang kuliner.

\section{Proses (Proccess)}

Proses pelayanan yang berlangsung di Bakso Super Rasa terbilang cepat mulai dari proses pemesanan hingga proses penyajian. Karyawan sangat tanggap dan cekatan merespon kebutuhan konsumen.

Bukti Fisik (Physical Evidence)

Bakso Super Rasa selalu mengutamakan konsumen, hal ini dibuktikan dengan bukti fisik yang ada di Bakso Super Rasa. Meskipun tempatnya hanya dengan menggunakan tossa tetapi pemilik memiliki cara sedemikian rupa untuk tetap mengutamakan kenyamanan konsumen saat membeli Bakso Super Rasa.

\section{Orang (People)}

Karyawan yang bekerja merupakan teman atau saudara dari karyawan yang lain. Karyawan juga tidak dituntut untuk memiliki keahlian dibidang makanan, yang terpenting yaitu pekerja keras, jujur dan cekatan.

\section{Data Eksternal}

Didaerah tempat berdirinya Usaha Bakso Super Rasa juga terdapat baksobakso sejenis yang juga menawarkan berbagai keunggulan yang dapat menjadi pesaing. Namun juga perlu dipertimbangkan hal-hal yang menjadi kunggulan dan kelemahan yang ada di daerah Bakso Super Rasa. pesaing di bidang kuliner yang sama karena para pemilik akan berlomba untuk mempertahankan usahanya dan menarik daya minat konsumen untuk menikmati produknya. Dengan adanya pesaing dapat menjadi acuan bagi pemilik dalam mengembangkan usahanya dengan cara tetap menjaga kualitas dengan baik dan terus berinovasi menciptakan menu baru yang dapat diminati konsumen, dan tetap memberi pelayanan yang baik kepada konsumen. 
Tabel IFAS (Internal Factor Analysis Summary)

\begin{tabular}{|c|c|c|c|c|}
\hline \multirow[t]{2}{*}{ No. } & $\begin{array}{l}\text { Faktor-faktor } \\
\text { Strategi Internal }\end{array}$ & B & $\mathbf{R}$ & B X R \\
\hline & Kekuatan & & & \\
\hline 1 & $\begin{array}{ll}\text { Pelayanan } & \text { terhadap } \\
\text { konsumen } & \end{array}$ & 0,20 & 4 & 0,80 \\
\hline 2 & $\begin{array}{l}\text { Memiliki hubungan } \\
\text { yang baik dengan } \\
\text { pelanggan. }\end{array}$ & 0,10 & 3 & 0,30 \\
\hline 3 & $\begin{array}{l}\text { Memiliki banyak } \\
\text { macam varian bakso. }\end{array}$ & 0,10 & 3 & 0,30 \\
\hline 4 & $\begin{array}{l}\text { Menjamin kualitas } \\
\text { dan kebersihan } \\
\text { produk bakso. }\end{array}$ & 0,10 & 3 & 0,30 \\
\hline \multirow[t]{3}{*}{5} & $\begin{array}{l}\text { Mendukung aplikasi } \\
\text { online. }\end{array}$ & 0,05 & 2 & 0,10 \\
\hline & Total & $\mathbf{0 , 5 5}$ & & $\mathbf{2 , 1}$ \\
\hline & Kelemahan & & & \\
\hline 1 & $\begin{array}{lr}\text { Masih } & \text { belum } \\
\text { memiliki tempat } & \text { temp yang tetap }\end{array}$ & 0,15 & 4 & 0,60 \\
\hline 2 & $\begin{array}{l}\text { Keterbatasan lahan } \\
\text { parkir }\end{array}$ & 0,10 & 3 & 0,30 \\
\hline 3 & $\begin{array}{ll}\text { Manajemen } & \\
\text { keuangan } & \text { masih } \\
\text { dilakukan } & \text { secara } \\
\text { manual } & \end{array}$ & 0,05 & 2 & 0,10 \\
\hline 4 & $\begin{array}{ll}\text { Kurangnya } & \text { fasilitas } \\
\text { pendukung } & \end{array}$ & 0,10 & 3 & 0,15 \\
\hline \multirow[t]{3}{*}{5} & $\begin{array}{l}\text { Dari segi harga lebih } \\
\text { mahal }\end{array}$ & 0,05 & 2 & 0,10 \\
\hline & Total & 0,45 & & $\mathbf{1 , 2 5}$ \\
\hline & $\begin{array}{ll}\text { Total } & \text { Skor } \\
\text { Internal } & \end{array}$ & $\mathbf{1}$ & & $\mathbf{3 , 3 5}$ \\
\hline
\end{tabular}

Dari analisis faktor internal diatas menunjukkan bahwa untuk faktor-faktor kekuatan sub total nilainya sebesar 2,1 sedangkan untuk faktor kelemahan sub total nilainya 1,25 .
Tabel EFAS (External Factor Analysis Summary)

\begin{tabular}{|c|c|c|c|c|}
\hline No. & $\begin{array}{l}\text { Faktor-faktor } \\
\text { Eksternal }\end{array}$ & $\mathbf{B}$ & $\mathbf{R}$ & B X R \\
\hline & Peluang & & & \\
\hline 1 & $\begin{array}{lll}\begin{array}{l}\text { Berada } \\
\text { strategis }\end{array} & \text { dilokasi } & \text { yang } \\
\end{array}$ & 0,20 & 4 & 0,80 \\
\hline 2 & $\begin{array}{l}\text { Memiliki pelanggan yang } \\
\text { tetap }\end{array}$ & 0,15 & 3 & 0,45 \\
\hline 3 & $\begin{array}{l}\text { Dapat menguasai pangsa } \\
\text { pasar }\end{array}$ & 0,10 & 3 & 0,30 \\
\hline 4 & $\begin{array}{l}\text { Membuka cabang di tempat } \\
\text { lain }\end{array}$ & 0,10 & 3 & 0,30 \\
\hline \multirow[t]{3}{*}{5} & $\begin{array}{l}\text { Berkembangnya } \\
\text { kuliner saat ini }\end{array}$ & 0,05 & 2 & 0,10 \\
\hline & Total & 0,60 & & $\mathbf{1 , 9 5}$ \\
\hline & Ancaman & & & \\
\hline 1 & $\begin{array}{l}\text { Banyak pesaing di } \\
\text { lingkungan sekitar }\end{array}$ & 0,15 & 4 & 0,60 \\
\hline 2 & $\begin{array}{l}\text { Harga bahan baku tidak } \\
\text { menentu }\end{array}$ & 0,10 & 3 & 0,30 \\
\hline 3 & $\begin{array}{l}\text { Perilaku konsumen yang } \\
\text { bisa berubah }\end{array}$ & 0,05 & 2 & 0,10 \\
\hline 4 & $\begin{array}{l}\text { Kemungkinan adanya isu } \\
\text { negatif }\end{array}$ & 0,05 & 2 & 0,10 \\
\hline \multirow[t]{3}{*}{5} & $\begin{array}{l}\text { Masyarakat modern lebih } \\
\text { menyukai masakan modern } \\
\text { dan cepat saji }\end{array}$ & 0,05 & 2 & 0,10 \\
\hline & Total & $\mathbf{0 , 4 0}$ & & $\mathbf{1 , 2}$ \\
\hline & Total Skor Eksternal & 1 & & 3,15 \\
\hline
\end{tabular}

Dari analisis faktor ekstenal diatas menunjukkan bahwa faktor peluang sub total nilainya sebesari 1,95 , sedangkan untuk faktor ancaman total nilainya sebesar 1,2 . 


\section{Diagram Analisis SWOT}

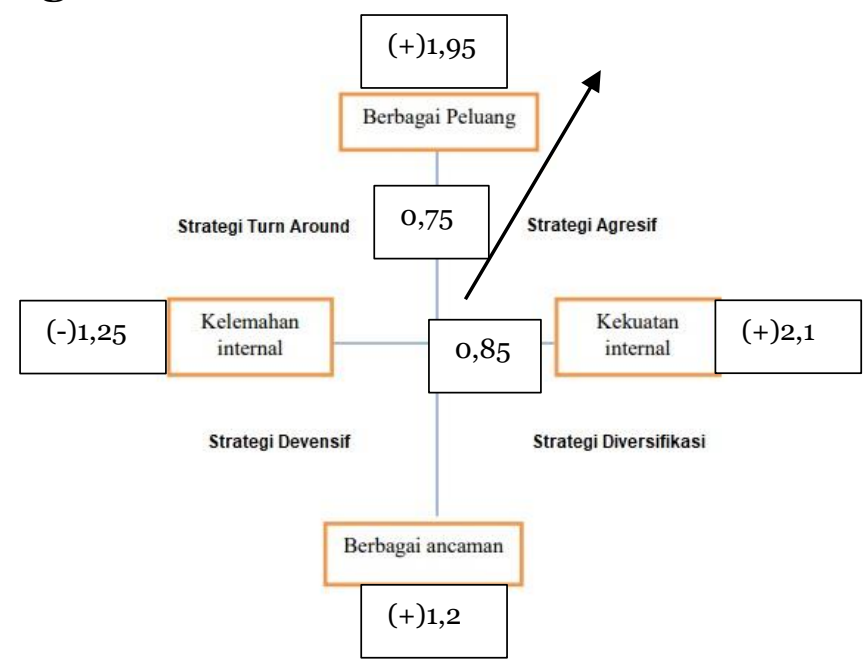

Dari diagram SWOT diatas dapat disimpukan bahwa Bakso Super Rasa berada di kuadran 1. Hal ini merupakan situasi yang menguntungkan karena perusahaan memiliki peluang dan kekuatan sehingga dapat memanfaatkan peluang yang ada. Strategi yang harus diterapkan dalam hal ini adalah mendukung kebijakan pertumbuhan yang agresif (growth oriented strategy).

\section{Rumusan Strategi Matriks SWOT}

\begin{tabular}{|l|l|l|}
\hline IFAS EFAS & $\begin{array}{l}\text { Strengths } \\
\text { (Kekuatan) } \\
\text { S }\end{array}$ & $\begin{array}{c}\text { Weakness } \\
\text { (Kelemahan) } \\
\text { W }\end{array}$ \\
\hline $\begin{array}{l}\text { Opportunities } \\
\text { (Peluang) }\end{array}$ & $\begin{array}{l}\text { Strategi } \\
\text { SO }\end{array}$ & $\begin{array}{l}\text { Strategi WO } \\
1,25+1,95= \\
\text { O }\end{array}$ \\
$\begin{array}{l}2,1+1,95= \\
3,25\end{array}$ \\
\hline Threats & Strategi ST & Strategi WT \\
(Ancaman) & $2,1+1,2=$ & $1,25+1,2=$ \\
T & 3,3 & 2,45 \\
\hline
\end{tabular}

\section{Matriks SWOT}

\begin{tabular}{|c|c|}
\hline $\begin{array}{l}\text { Strategi SO } \begin{array}{r}\text { (memiliki } \\
\text { untuk } \\
\text { kekuatan } \\
\text { memanfaatkan peluang) }\end{array} \\
\text { 1. Memberi pelayanan yang } \\
\text { terbaik kepada konsumen } \\
\text { untuk mempertahankan } \\
\text { pelanggan tetap. } \\
\text { 2. Berinovasi dan kreatif } \\
\text { memproduksi berbagai } \\
\text { macam bakso dengan } \\
\text { mempertahankan kualitas } \\
\text { dan kebersihan produk } \\
\text { supaya dapat terus } \\
\text { berkembang dan menguasai } \\
\text { pangsa pasar. } \\
\text { 3. Memanfaatkan aplikasi } \\
\text { makanan online agar dapat } \\
\text { memudahkan konsumen } \\
\text { saat melakukan pembelian. }\end{array}$ & $\begin{array}{l}\text { Strategi WO (memiliki } \\
\text { peluang besar dan } \\
\text { meminimalkan } \\
\text { kelemahan) } \\
\text { 1. Menfaatkan lokasi yang } \\
\text { strategis dengan } \\
\text { membuka tempat usaha } \\
\text { yang memiliki fasilitas } \\
\text { agar dapat menarik minat } \\
\text { konsumen. } \\
\text { 2. Meningkatkan sistem } \\
\text { keuangan agar dapat } \\
\text { mengembangkan } \\
\text { usahanya sehingga dapat } \\
\text { mempertahankan } \\
\text { pelanggan tetap. } \\
\text { 3. Meminimalisir harga } \\
\text { agar dapat menguasai } \\
\text { pangsa pasar. }\end{array}$ \\
\hline $\begin{array}{l}\text { Strategi } \\
\text { (menggunakan kekuatan } \\
\text { untuk mengatasi } \\
\text { ancaman) } \\
\text { 1. Memberikan pelayanan } \\
\text { baru terhadap konsumen } \\
\text { agar dapat bersaing dengan } \\
\text { pesaing dilingkungan } \\
\text { sekitar. } \\
\text { 2. Menjamin kualitas yang } \\
\text { diberikan agar dapat } \\
\text { menarik pelanggan dan } \\
\text { dapat menangkal adanya isu } \\
\text { negatif tentang bakso. } \\
\text { 3. Selalu berinovasi } \\
\text { memproduksi jenis bakso } \\
\text { yang sedang trend } \\
\text { dikalangan masyakarat agar } \\
\text { dapat menarik minat } \\
\text { konsumen. }\end{array}$ & 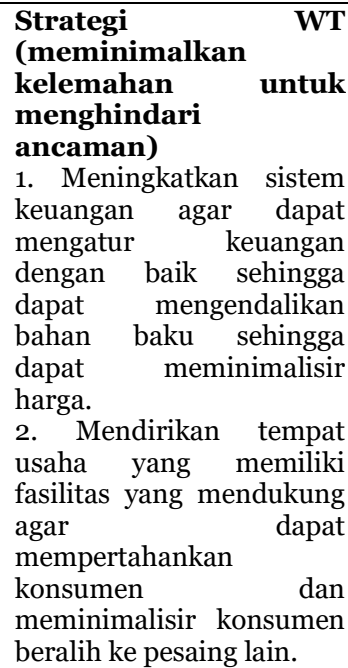 \\
\hline
\end{tabular}

\section{Pembahasan}

Analisis SWOT Faktor Internal dan Faktor Eksternal Usaha Bakso Super Rasa

1. Kekuatan (Strenghts)

a) Memproduksi berbagai macam jenis bakso seperti bakso halus, bakso kasar, bakso kotak, bakso keju, bakso mercon dan bakso mekar besar dan pelengkap tahu tengiri udang, siomay tengiri udang, goreng panjang, goreng bulat. Sebagai pelengkap dalam memakan bakso, usaha ini juga memiliki topping daging cincang.

b) Memberikan pelayanan yang terbaik terhadap konsumen, pelayanan tersebut dengan cara selalu ramah terhadap konsumen yang datang, 
melayani dengan senyuman pesanan konsumen.

c) Karyawan telah bekerja cukup lama sehingga telah memiliki pengalaman, karyawan juga memiliki sifat ramah, pekerja keras, ulet dan jujur.

2. Kelemahan (Weakness)

a) Dalam segi tempat, hanya berjualan dengan menggunakan tossa dengan itu maka memiliki tempat yang terbatas apabila pelanggan memakannya ditempat

b) Dalam segi mengelola keuangan, belum maksimal karena dalam manajemen keuangan masih dilakukan secara manual.

3. Peluang (Opportunities)

a) Terletak dilingkungan strategis di Jalan Gayungsari Timur, lokasi tersebut terletak dilingkungan yang ramai dilalui masyarakat karena dekat dengan Masjid Al Akbar Surabaya, perkantoran, sekolahan dan pemukiman padat penduduk.

b) Memiliki peluang besar untuk menguasai pangsa pasar karena target konsumen yaitu anak-anak, mahasiswa, dan orang tua. Dengan memberikan pelayanan yang terbaik memberikan kepuasan bagi konsumen maka dapat menajdi potensi besar yang juga,

c) Berdiri sejak 2010 dan dapat bertahan hingga saat ini dapat menjadi peluang besar karena sudah memiliki pelanggan yang tetap.

4. Ancaman (Threats)

a) Adanya pesaing dengan usaha serupa saat ini menjadi ancaman karena dapat membuat pelanggan menjadi ingin mencoba bakso ditempat yang lain.

b) Perilaku konsumen yang mudah merasa bosan juga menjadi ancaman serius bagi pemilik usaha, konsumen saat ini lebih menyukai makanan yang modern seperti pizza.

\section{Formulasi Strategi}

Berada pada kuadran 1 yaitu perusahaan berada pada situasi yang menguntungkan karena memiliki peluang dan kekuatan sehingga dapat mememanfaatkan peluang yang ada dan didukung dengan kekuatan yang dimiliki. Strategi yang harus diterapkan mendukung kebijakan pertumbuhan yang agresif. Strategi yang diterapkan untuk mengembangan usaha ini adalah dengan cara mempertahankan kualitas produk sehingga konsumen memiliki kepuasan saat mengkonsumsinya, tetap mempertahankan kerja sama dengan baik dengan pelanggan dan tetap untuk meningkatkan kepercayaan konsumen, selalu berinovasi menambah variasi yang sedang disukai konsumen untuk memenuhi keinginan konsumen, serta mendirikan tempat untuk berjualan sehingga dapat membuat konsumen nyaman saat membeli.

\section{Skala Prioritas Stretegi}

Hasil dari rumusan yang pertama yaitu SO karena mempunyai nilai paling tinggi dengan nilai 4,05, yang kedua yaitu ST memiliki nilai 3,3 , yang ketiga WO memiliki nilai 3,2 dan yang terakhir WT memiliki nilai paling rendah yaitu 2,6.

\section{A Strategi SO}

1. Memberikan pelayanan terbaik kepada konsumen untuk mempertahankan pelanggan tetap.

2. Berinovasi dan kreatif memproduksi berbagai jenis bakso dengan mempertahankan kualitas dan kebersihan produk.

3. Memanfaatkan aplikasi makanan online agar mempermudah konsumen saat melakukan pembelian.

B Strategi ST

1. Memberikan pelayanan baru terhadap konsumen agar dapar bersaing dengan pesaing di lingkungan sekitar.

2. Menjamin kualitas yang diberikan agar dapat menarik pelanggan dan menangkal isu negatif tentang bakso. 
3. Berinovasi memproduksi jenis bakso yang sedang trend dikalangan masyarakat.

C Strategi WO

1. Memanfaatkan lokasi yang strategis dengan membuka tempat usaha yang memiliki fasilitas yang memadai.

2. Meningkatkan sistem keuangan agar dapat mengembangkan usahanya.

3. Meminimalisir harga agar dapat menguasai pasar.

D Strategi WT

1. Meningkatkan sistem manajemen keuangan agar dapat mengendalikan bahan baku.

2. Mendirikan tempat usaha yang memiliki fasilitas mendukung agar konsumen tidak berpindah ke pesaing lain.

\section{KESIMPULAN}

1. Melalui analisa yang telah dilakukan maka Bakso Super Rasa memiliki kekuatan yang dimiliki secara internal dan dapat memenafaatkan peluang yang ada meakipun memiliki kelemahan dan ancaman dalam usahanya.

2. Usaha Bakso Super Rasa berada pada kuadran 1 yaitu perusahaan berada pada situasi yang menguntungkan karena memiliki peluang dan kekuatan sehingga dapat mememanfaatkan peluang yang ada dan didukung dengan kekuatan yang dimiliki.

3. Hasil dari rumusan startegi matriks SWOT yang memiliki nilai paling tinggi yaitu ke strategi SO. Strategi yang bisa diterapkan yaitu:

a Memberikan pelayanan yang terbaik kepada konsumen untuk menarik minat konsumen dan mempertahankan pelanggan tetap.

b Berinovasi dan kreatif menciptakan dan memproduksi berbagai macam jenis bakso dengan tetap mempertahankan kualitas dan kebersihan produk. c Memanfaatkan aplikasi makanan online agar dapat memudahkan konsumen saat melakukan pembelian karena konsumen tidak perlu datang ke tempat saat akan melakukan pembelian.

\section{SARAN}

1. Dari hasil analisis SWOT Bakso Super Rasa memiliki kelemahan yang cukup fatal sehingga sebaiknya diminimalkan seperti masih belum memiliki tempat usaha dengan lahan yang besar, hendaknya pemilik dapat memperluas tempat usaha dengan memberikan fasilitas yang memadai dan lahan parkir sehingga konsumen bisa makan ditempat dengan nyaman.

2. Sebaiknya pemilik Bakso Super Rasa dapat meningkatkan sistem manajemen keuangan karena dengan manjemen keuangan yang baik maka dapat harga bahan baku jika ada kenaikan dan dapat meminimalkan harga jual produk.

3. Memperluas sistem pemasaran dengan menggunakan sosial media sehingga dapat memperluas pasar yang lebih luas.

\section{DAFTAR PUSTAKA}

Abdul Rivai dan Darsono Prawinegoro. 2015. Manajemen Strategis. Jakarta: Mitra Wacana Media.

Abdullah, Thamrin dan Francis Tantri. 2016. Manajemen Pemasaran. Depok: PT Raja Grafindo Persada Aji, Prasetio. (2015). Manajemen Strategi: Keunggulan Bersaing Berkelanjutan. Yogyakarta: Ekuilibria

Cindy Rienaya, Mudatsir Najamuddin, Akhmad Mahbubi, 2017. Strategi Bisnis Kopi Merek Coffesso PT 
David Roy Indonesia. UIN Syarif Hidayatullah Jakarta.

Fitrah Rahmawati, Jamal Bake, Hj Ninik Endang Purwati. 2018. Analisis Strategi Pengembangan Bisnis Rumah Makan Wong Solo di Kendari. Universitas Halu Oleo Kendari Sulawesi Tenggara.

Irwan Sahaja. (2014). Pengertian Penjualan.

Johnson, G., Scholes, K., dan Whittington, R., 2008., Exploring Corporate Strategy. 8 Edition. Boston: Prentice Hall.

Rangkuti, Freddy 2017. Analisis SWOT Teknik Membedah Kasus Bisnis Cetakan Keduapuluh Tiga. Jakarta : PT Gramedia Pustaka Utama

Rangkuti, Freddy. 2013. Teknik Membedah Kasus Bisnis Analisis SWOT Cara Perhitungan Bobot, Rating, dan OCAI. Penerbit PT. Gramedia Pustaka Utama. Jakarta

Sadono, Sukirno. 2010. Makro Ekonomi. Teori Pengantar. Edisi Ketiga. PT. Raja Grasindo Perseda. Jakarta.

Salusu, J. 2007. Pengambilan Keputusan Stratejik. Jakarta: PT Gramedia Pustaka Utama

Siagian, Sondang., P. 2008. Manajemen Sumber Daya Manusia Jakarta: Binapura Aksara

Soehardi, S., \& Sable, S. C. (2019). Strategi

Pemasaran Bisnis Pariwisata Di Kota Davao, Filipina. Jurnal Ilmiah Manajemen Ubhara, 1(2), 1-13. https://doi.org/http://dx.doi.org/10.3 1599/jmu.v1i2.674

Sugiono, Memahami Penelitian Kualitatif, Bandung: Alfabeta, 2012.

Sugiyono. (2017). Metode Penelitian Kuantitatif, Kualitatif, dan $R \& D$. Bandung: Alfabeta, CV.

Tohar, Muhammad. Membuka usaha kecil. Kanisius, 2000.
Undang Undang. Tahun 2008 tentang UMKM (Usaha Menengah Kecil dan Mikro). 